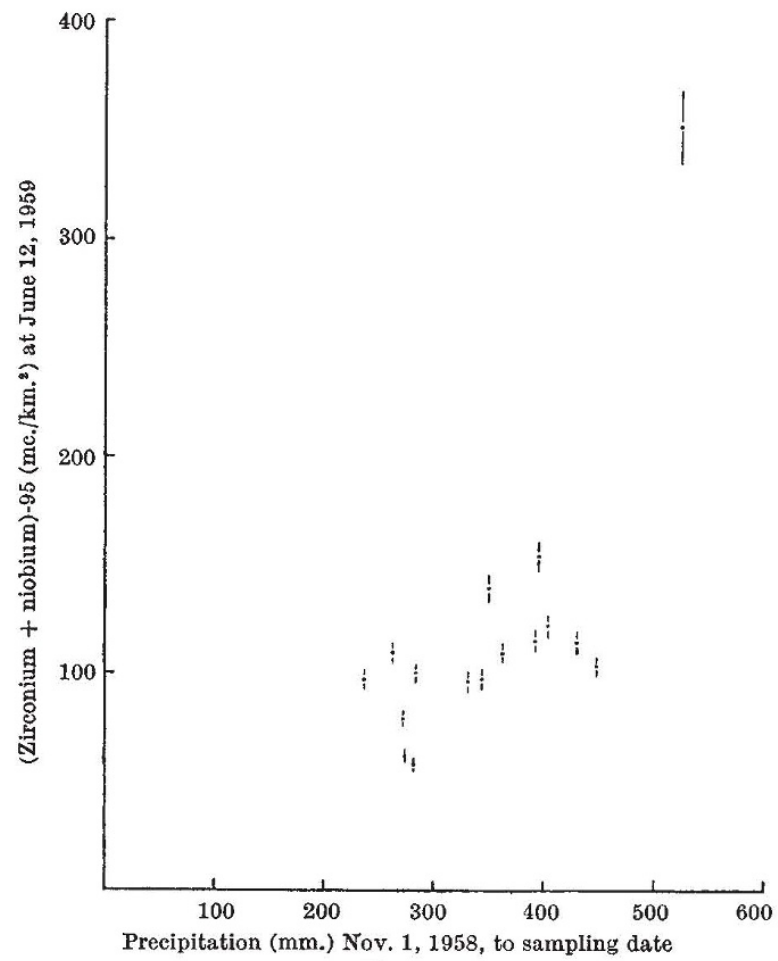

Fig. 3

since the beginning of considerable global fall-out, and the zirconium + niobium-95 deposit with the precipitation since the autumn, 1958.

As can be seen in Figs. 2 and 3, a strong linear relationship seems to exist between cæsium-137 deposit and precipitation $(\rho=0.99$ with the 95 per cent confidence limit 0.95 and 1.00$)$, whereas the zirconium + niobium -95 values are more scattered ( $p=0.74$ with the 95 per cent confidence limits $0 \cdot 35$ and 0.90 ). In the case of zirconium + niobium95, the value for Bergen has not been included because of the later sampling date.

The larger irregularities in the zirconium + niobium-95 values are not unexpected. Large variations in the specific activity of precipitation have been observed between samples taken simultaneously at different locations ${ }^{5}$, and such variations will be reflected in Fig. 2. Corresponding variations in the case of cæsium-137 will be levelled out because of the long period of accumulation. Of course it is

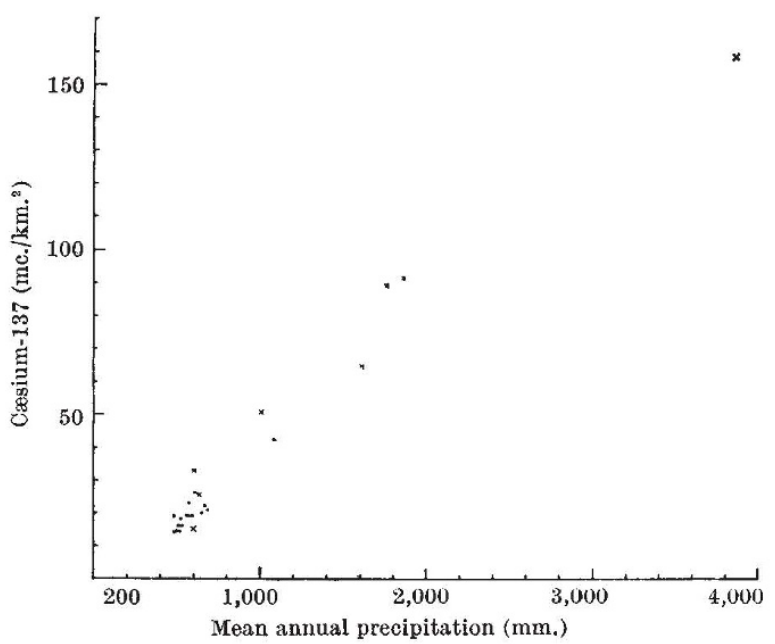

Fig. 4

also quite possible that the variations in the specific cæsium-137 activity in precipitation are smaller.

If the values for Bergen and station 1 are excluded the mean value of the cæsium-137 deposit is 18.7 $\mathrm{mc} . / \mathrm{km} .{ }^{2}$ and the standard deviation is $3.5 \mathrm{mc} . / \mathrm{km} .{ }^{2}$. The corresponding precipitation values vary within \pm 20 per cent. This precipitation interval applies to the greater part of Sweden, and the above value can thus be regarded as a reasonable mean value for the country.

Peirson has recently published a corresponding study concerning the deposit in the United Kingdom on samples taken during the summer, $1959^{3}$. In Fig. 4, Pierson's and our values of the cæsium-137 deposit are plotted against the mean annual precipitation. No significant differences between the two sets of values can be detected. As the latitude of the British sampling sites is $50-55^{\circ} \mathrm{N}$., while the Swedish sites are at $60-63^{\circ} \mathrm{N}$., this concordance is of interest.

For the selection of sampling sites and for carrying out the sampling we are indebted to Dr. L. Fredriksson at the Royal Agricultural College, Ultuna.

1 Gustafson, P. F., Science, 127, 1240 (1958).

${ }^{2}$ Löw, K., and Edvarson, K., Nature, 183, 1104 (1959).

${ }^{8}$ Peirson, D. H., and Salmon, L., Nature, 184, 1678 (1959).

4 Edvarson, K., and Löw, K., The Concentration of Some Fission Product Nuclides in the Ground Level Air during the Period Sept. s Lindblom, G. (private communication).

\title{
OBITUARY
}

\section{Prof. Max von Laue, For.Mem.R.S.}

Prof. Max von LaUe, former director of the FritzHaber-Institut of the Max Planck Gesellschaft in Berlin Dahlem, died in Berlin on April 24 a few months after his eightieth birthday.

In an autobiographical note, Max von Laue once described the early influence upon him of his excellent science teacher at the Gymnasium in Strassburg, and also his great interest in H. v. Helmholtz's popular lectures. These were the determining factors which made him choose physics and mathematics, and in 1898 he began to read physics at the University of Strassburg - probably against the will of his father and step-mother, who would have liked him to become an officer in the Prussian Army. In 1899 he moved to Göttingen, where he came under the spell of David Hilbert, whom he regarded as probably the greatest genius he ever met in his life. However, it was Waldemar Voigt who taught him to apply mathematical methods to physics. v. Laue became a theoretical physicist, and, after a short interlude in 
Munich-short, because Boltzmann's chair was still vacant and there was no one to teach thooretical physies-he went to Berlin. It is likely that during these years, 1902-4, the fundamentals were laid for the discovery which, ten years later, brought Laue world fame and a Nobol Prize in Physics. It was indeed one of the greatest discoveries of the century. He attended Max Planck's lectures on theoretical optics and Lummer's on spocial problems of optics. Laue remarked that during these formative year's ho acquired his 'optical instinct' which stood him in such good stead later. The subject given to him by Planck for his dissertation was "Theory of Interference on Plane Parallel Plates".

Laue became the devoted pupil of Planck, and Berlin his spiritual home. After two more years postgraduate work in Göttingen, he returned in 1905 to Berlin as lecturer and as Planck's assistant. It was Einstein's annus mirabilis. Laue's early work on relativity-with his many contributions to thermodynamies, the theory of radiation and also his phenomenological theory of superconductivity-seem, to-day, unjustly eclipsed by his X-ray diffraction work. It led to his monograph on the special theory of relativity (1910) - the first ever written-and later to another on the general theory of relativity.

In 1909 , v. Laue moved to Munich, and it was there, in 1912, that he made one of the greatest and most far-reaching discoveries of our own age, the diffraction of X-rays by crystals. The scientific atmosphere in Munich at this time was especially favourable for this discovery. W. C. Röntgen was still active, and $\mathrm{A}$. Sommerfeld, a firm boliever in the wave nature of $X$-rays, had succeeded Boltzmann. Sommerfeld's influence in theoretical physics through his own research and by his teaching was probably greater than that of anyono olse. Also in Munich was P'aul von Groth, the mineralogist, continuing the tradition of Leonhard Sohncke, who in his time had contributed greatly to the theory of crystals. There was, too, young P. P. Ewald seeking advice on wave optics, whose work suggested to v. Laue the idea of the experiment performed by $W$. Friodrich and $P$. Knipping. The second experiment, using copper sulphate as crystal, showed the result which v. Laue predicted. Many research worker's before this had sent $X$-rays through crystals, limiting their observations to the direct beam, without noticing anything of interest. It was left to v. Laue's genius to expect, and find, diffracted rays on the photographic plate. The theory of one- and two-dimensional gratings, so well known to v. Lauc, was casily extended to a threc-dimensional grating such as he proved to exist in the regular arrangement of atoms in crystals. Max von Laue's discovery was made "by the sheer power of believing more concretuely than anyone elso in the accepted theory of crystals and X-rays. These advances were no less bold and hazardous than were the innovations of Copernicus, Planck or Einstein" (M. Polanyi).

It is impossible to describe shortly the ennsequences of this discovery on the development of almost every branch of science. This door, opened in 1912, is still wide open nearly fifty years later. Only recently the results have been described in Nature of fundamental work by Kondrew and Perutz which would not have been possible but for the historical experiment in Munich. Sir Lawrence Bragg, confining himself to X-ray analysis only, has given a masterly account of the advances in the determination of crystal struc- tures in a volume dedicated to three octogenariansLise Meitner, Otto Hahn and Max von Laue. v. Laue himself was never interested in developing his discovery into a tool for crystal structuro analysis; instead, he followed the course of developing the optical background of X-ray diffraction, work which is recorded in the various editions of his book, "Röntgenstrahl Interferenzen".

Aftor a short spell as professor in Zurich and Frankfurt, von Laue returned to Berlin as professor of theoretical physics and co-dircetor, with his lifelong friend, A. Einstein, of the Kaiser-WilhelmInstitut für Physik. He remained in Berlin all his life, becoming, after the Second World War, director of the Fritz-Haber-Institut. Well over 200 papers, on almost every aspect of theoretical physics, and a number of books-among them a short history of physies-were the result of his work. However, in spite of his lively interest, he never contributed to the development of quantum mschanics. He shared, with his fricnds Planck and Einstein, certain reservations towards its final consequences.

Berlin, after tho First World War and before 1933, had become one of the great centres of learning. A regular scientific event was the "Laue Colloquium" at the Physics Department in Reichstagsufer, unforgettable to anybody who had the good fortune to attend it regularly. Every week, and under the ehairmanship of v. Laue, there took place a gathering of eminent mon of science, of those who later became eminent, and of everybody else interested in new developments of physics. Planck, N $\rightarrow$ rnst, Einstein, Schroedinger, Lise Meitner, R. Ladenburg and, later, Dobye and G. Hertz all attended regularly. Among those who came to great eminence later on were $F$. Simon, J. von Neumann, I. Szilard, E. Wigner and F. London. It was a very democratic institution, and overybody was allowed to ask quostions, intelligent and, sometimes, silly ones. All this, and the spiritual values of this period, came to an abrupt end in 1933. The material destruction which followed during the War was a direct consequence of the political events of 1933. It was during these fateful years that von Laue showed the greatness of his personality. $\mathrm{He}$ became a lonoly and vory courageous fighter for truth and integrity against tyranny and the evils of a wicked regime. He was probably tho only member of the Academy who launched a solemn protest against Einstein's expulsion from the Prussian Academy of Sciences. The era of 'Aryan physics' began, and it was decreed, mainly by obscure men, but unfortunately also by two great physicists, who sprang out of oblivion, that Einstein's and other Jewish physicists' names and work must in future be ignored. Again, it was Laue, at a meeting of the German Physical Society (Würzburg, September 1933), who replied spontaneously to an address by Johannes Stark on the role and task of physics in the Third Reich. Laue reminded the andience that, almost exactly 300 years before, Galileo was forced, under threat of torture by the Inquisition, to renounce his doctrine. $\mathrm{He}$ passionately appealed to the physicists to bear in mind Galileo's famous words: "It moves, nevertholess!" The following year his obituary of Fritz Haber, published in Die Naturwissenschaften, would havo had dangerous consequeneos for $v$. Laue had not the Gestapo been afraid of the reaction of the civilized world to the porsecution of the man who dared to say: "Just as Themistocles has become immortal as the victor of 
Salamis, and not as the conqueror of the Persian king, Fritz Haber has become immortal by his scientific work".

During the War, v. Laue became somewhat of a recluse. His only son was safe in the United States studying history. His house, where he lived with his wife and daughter, was visited by a handful of friends who thought as he did, by the sons and friends of Dutch and Norwegian scientists sent as slave workers to Germany, by French prisoners of war and many more who needed his help or advice. In 1941 he went with half a dozen friends to the derelict Jewish cemetery to pay his last respects to his old friend, Dr. Arnold Berliner, founder and, for twenty-five years, editor of Die Naturwissenschaften. Berliner had been forced to resign by the Nazis, and had committed suicide rather than be expelled from his home and sent to a concentration camp. Carbon copies of the obituary Laue wrote were sent to several of his friends for safe keeping, and published after the War. v. Laue never had the slightest doubt that Germany would lose the War. In 1943 he was seriously rebuked by the Nazi Minister of Education for mentioning Einstein's name in a lecture. In reply to this, he published shortly afterwards a paper, "Ein relativistischer Beweis für das Wien'sche Verschiebungsgesetz".

When the end of the War came, v. Laue was in Hechingen, where the Institute had been evacuated. With a team of German atomic scientists, known as the 'Uran-Verein', v. Laue was sent as a 'prisoner' to England. Naturally, v. Laue was not 'trustworthy' enough to have become a member of this team, and in any event he would have refused his co-operation. Some of the letters he wrote to friends at this time about the reaction of his colleagues to Hiroshima, and their subsequent discussions on the atom bomb, are carefully preserved documents of great historical interest.

Returning to Germany, he put all his efforts into rebuilding science. In 1946 he was, with Max Planck, the first German to be invited to England. He received many honours and was elected a foreign member of the Royal Society in 1949. His ashes are buried at Göttingen cemetery beside the graves of Walther Nernst, Adolf Windaus and Max Planckfour members of a great period of science in Germany. P. ROSBAUd

\section{NEWS and VIEWS}

Botany at Adelaide : Prof. R. N. Robertson

Prof. R. N. Robertson, who is to succeed the late Prof. J. G. Wood as professor of botany in the University of Adelaide, graduated from the University of Sydney in 1934. In 1936, he went to St. John's College, Cambridge, as a Scholar of the Royal Commission for the 1851 Exhibition. After graduating with a Ph.D. degree in plant physiology, he joined the lecturing staff of the University of Sydney in 1939. In 1946 he joined the Commonwealth Scientific and Industrial Research Organization, in which he afterwards became a chief research officer and is now a member of the executive. With Prof. F. V. Mercer, he founded the Plant Physiology Unit, which is run jointly by the Department of Botany, University of Sydney, and the Organization's Division of Food Preservation and Transport. During 1958-59 Prof. Robertson was a visiting professor in the Department of Horticultural Science of the University of California at Los Angeles. His research has been concerned with problems of salt accumulation and respiration in plant cells and in plant mitochondria. In addition, he has carried out work on the developmental physiology of fruits with special reference to respiration. Because of his commitments to the Commonwealth Scientific and Industrial Research Organization's Executive, Prof. Robertson will not take up his duties in Adelaide until the beginning of 1962, and in the meantime Dr. H. B. S. Womersley has been appointed as acting-head of the Department.

\section{International Meteorological Organization Prize :} Prof. J. van Mieghem

The Executive Committee of the World Meteorological Organization has this year awarded the annual prize paid for from the funds left to it by the International Meteorological Organization to the eminent Belgian meteorologist, Prof. J. van Mieghem. The prize consists of a gold medal, 1,200 U.S. dollars and a diploma. Prof. van Mieghem is chief of the service for theoretical and experimental aerology of the Royal Meteorological Institute of Belgium. He is also professor of meteorology in the Free University of Brussels and chairman of the Belgian National Centre for Polar Research. In its selection, the Committee takes into account both scientific eminence and the record of work done in the field of international meteorological organization. Under the first heading, Prof. van Mieghem is a mathematician of the first order, who has published about a hundred papers on the dynamics and thermodynamics of the atmosphere, with the subject of energy transfurmations as his major field of research. His contributions to the international organization of meteorology are also very large. He was president of the Technical Commission for Aerology of the World Meteorological Organization during 1951-57, and in the International Union of Geodesy and Geophysics he has been secretary (1948-54), vice-president (1954-57) and president (from 1957) of the International Association of Meteorology and Atmospheric Physics. Probably his major work in this sphere, however, was as chairman of the World Meteorological Organization Working Group for the International Geophysical Year and representative of the Organization on the Special Committee for the International Geophysical Year.

\section{The Swinburne Medal of the Plastics Institute}

The first award of the Swinburne Medal of the Plastics Institute has been made to Prof. G. Gee, professor of chemistry in the University of Manchester, for his outstanding contributions to the advancement of polymer chemistry. Prof. Gee will deliver his Swinburne Address at the Royal Institution on Thursday, February 16, 1961, when he will be presented with the Gold Medal and the sum of money which accompanies the award. The award was instituted in 1959 to commemorate Sir James Swinburne, who died at the age of a hundred in the previous year; it has been generously endowed by Bakelite, Ltd. 